\title{
Peri-urban agricultural development in Beijing: Varied forms, innovative practices and policy implications
}

\author{
Zhenshan Yang a , Pu Hao ${ }^{b}$, Weidong Liu ${ }^{a}$, Jianming Cai ${ }^{a}$ * \\ ${ }^{a}$ Key Lab of Regional Sustainable Development and Modelling, Institute of Geographical Sciences and Natural Resources Research, Chinese Academy of \\ Sciences, 11A Road, Datun, Chaoyang, Beijing, 100101, China \\ b David C. Lam Institute for East-West Studies, Hong Kong Baptist University, Kowloon Tong, Hong Kong, China
}

\section{A R T I C L E I N F O}

\section{Article history:}

Received 25 February 2016

Received in revised form

7 May 2016

Accepted 2 June 2016

Available online 15 June 2016

\section{Keywords:}

Peri-urban agriculture

Rural development

Urban-rural interaction

Regional development

Beijing

\begin{abstract}
A B S T R A C T
Agriculture in peri-urban areas is prone to dynamic changes due to urban influences. Previous studies have explored the impact of urban growth on peri-urban agriculture (PUA), but the active responses of the agricultural sector are rarely examined. This paper investigates recent agricultural development practices in peri-urban Beijing and explores approaches to agricultural transformation in the rapid process of urbanisation. The investigation finds that high-tech precision agriculture, down-stream processing and agro-tourism have emerged as major forms of PUA in Beijing. It also uncovers that the PUA developments are not only economically appealing, but also socially inclusive and environmental friendly. The findings contribute to a better understanding of PUA progress in China. The paper suggests policy implications in facilitating integrated development between urban and rural sectors, which would help improve economic development, spatial planning and local governance in peri-urban areas.
\end{abstract}

() 2016 Elsevier Ltd. All rights reserved.

\section{Introduction}

As an interface between city and countryside, peri-urban areas significantly affect urban transformation and expansion. In many countries, rapid urban growth has overshadowed progress in agricultural development (Lin \& De Meulder, 2012). Agricultural sectors are usually disadvantaged when competing for labour and land, which inevitably leads to stagnation or even decline (Hamilton et al., 2014). The gap between urban and rural development has widened due to discrepancies in developmental goals, cultural identity and environmental circumstances (Hao, 2012). These discrepancies, if not properly addressed, could form an obstacle to sustainable growth in urban and peri-urban areas (Bezemer and Headey, 2008; Higgins, 1956). Agricultural sectors are discouraged from expanding or upgrading, while urban explosion has jeopardised food production and environmental

\footnotetext{
* Corresponding author.

E-mail addresses: yangzs@igsnrr.ac.cn (Z. Yang), puhao@me.com (P. Hao), liuwd@igsnrr.ac.cn (W. Liu), caijm@igsnrr.ac.cn (J. Cai).

1 Abbreviations: PUA, peri-urban agriculture; FHSA, farmer-household-based sightseeing agriculture; ERAP, enterprise-based recreational agriculture parks; XGR, Xiedao Green Resort; MBFG, Mutual Benefit Food Group; XTS, Xiaotangshan; TIUAHTP, Tongzhou International Urban Agriculture High-Tech Park; GFVC, Green Fruit and Vegetable Cooperative.
}

conservation. Under these circumstances, peri-urban agriculture $(\mathrm{PUA})^{1}$ has emerged as an innovative model of agricultural development, in which rural communities respond to urban growth and practice new agricultural activities, exhibiting the potential to fuse rural and urban economies (Broadway, 2009; Mougeot, 2006; Shillington, 2008).

PUA make multifaceted responses that coincide with many crucial needs related to the agricultural sector and rural land, including food production, rural restructuring, poverty reduction and environmental protection (Ellis \& Sumberg, 1998; Saifi \& Drake, 2008). Agriculture in and around urban areas is refunctionalised (Adeyemi, 2000) to provide spaces for improving agricultural practices and enhancing current urban-rural complementarity (Yang, Cai, \& Sliuzas, 2010). However, we need to properly amend current rural and agricultural policies to respond to radical changes in PUA and incorporate the multiple goals into a rural development scheme (Marsden \& Sonnino, 2008).

PUA differ considerably from place to place, because urban-rural relationships and farming systems in and around cities vary across regions (Dubbeling, 2014; Ellis \& Sumberg, 1998; Hamilton et al., 2014). African PUA development is mainly focused on food and fuel production, which relates to alleviating hunger and poverty (Ellis \& Sumberg, 1998; Lee-Smith, 2010). European PUA emphasizes the ecological values of green spaces and their associated 
social values such as recreation and therapeutic treatment (City Farmer, 2007; Holland, 2004; Milligan et al., 2004). Although economy and production have been much liberalized after economic reform, agriculture is strongly supported and controlled by the government to a large extent especially in Beijing and most inland cities where municipal governments are highly dominated even in economic development (Yang, Cai, \& Ottens, Sliuzas, 2013). Thus, PUA accompanies penetration of urban economies into rural areas and the growth of farmer entrepreneurs. In return, the bottom-up development of PUA generates valuable policy implications for urban and rural development within rapid urban transition.

This paper examines the practice and innovations of PUA development in Beijing, China and contributes to the literature on agricultural development in rapidly transforming peri-urban areas. Owing to its capital status and high level of urbanisation, Beijing is a pilot city engaging in PUA development in China. According to the 2010 Census, Beijing municipality houses 21 million inhabitants, about 7 million of which are migrants (Beijing Statistical Bureau, 2011). The $16,808 \mathrm{~km}^{2}$ territory consists of 11 urban districts and 1 county (Fig. 1). Xicheng and Dongcheng districts form the city proper, and other districts make up the rest of it and its rural peripheries. From 1978 to 2010, the proportion of urban population increased from $55 \%$ to $85 \%$ and urban development greatly outpaced and outweighed rural development.

Agriculture in peri-urban Beijing used to be marginalised (Tan, 2014), particularly from 1992 to 2004. The agricultural sector has declined steeply since 1992 , losing 145,000 jobs and 65,000 ha of land (Beijing Statistical Bureau, 2013). Since the mid-1990s, PUA has emerged and gained popularity among farmers and urban residents.

By comparison, conventional agriculture is less competitive than urban sectors in terms of economic returns and product diversification. This is perhaps a weakness for the economic justification of agriculture, and much agricultural land is replaced by urban uses (De Zeeuw et al., 2011, van Veenhuizen, 2006). Therefore, this paper examines three related questions: (1) What kind of agricultural activities recently emerged due to urban-rural interactions? (2) Are these activities economically competitive and sustainable? (3) To what extent do these activities contribute to strengthening urban and rural integration? Also, the paper examines whether Chinese practices differ from African hunger and poverty alleviation programmes or European services and recreation-oriented exercises.

In order to fulfil these, an investigation was conducted through surveys and in-depth interviews with farmers, migrants and entrepreneurs during 2004-2013. More specifically, in August 2004, May 2005, September 2008, and September 2012, a series of surveys were made with firms, agro-parks, farmers, farmer cooperatives, and governments. In addition, we frequently contacted with them by emails and telephones to keep tracking their progress during 2004-2013. Discussions with government officials from Beijing Municipal Agricultural Bureau, Beijing Agricultural Committee, and Shunyi and Huairou District Agricultural Bureaus helped to gain understanding of the policy-making process at different levels of agricultural authorities. The questions are summarised in Appendix 1, which documents the time, stakeholders and key questions. Relevant policies, statistical data and enterprise documents were reviewed to supplement the primary data. These surveys and interviews help (1) to understand local PUA innovation; (2) to evaluate the performance of PUA activities in terms of economic, social and environmental outcomes, and; (3) to determine whether these activities contribute to rural and urban development. To illustrate the variety in PUA practices, four representative cases from different genres were examined with respect to macro policy changes in this article.

\section{Peri-urban agriculture and its multifunctionality}

PUA involves territorial, industrial and institutional dimensions. It implies an inherent connection between urban spaces and agriculture, two entities that seem incompatible. However, agriculture in and around urban areas is influenced by urban development. Geographical proximity allows peri-urban areas to develop new forms of agriculture to secure an alternative local food supply (Jarosz, 2008) and preserve the rural landscape (Clark, Jones, Potter, \& Lobley, 1997, Daugstad, 2008).

Multifunctionality features PUA and makes it different from conventional agriculture, enabling vigorous development of PUA in a rather urbanised society (De Zeeuw, Van Veenhuizen, \& Dubbeling, 2011; Zasada, 2011). "Multifunctional agriculture" refers to agriculture-related activities that create commodity and non-commodity outputs to satisfy market demands and public requirements (Bjørkhaug \& Richards, 2008; Buller \& Morris, 2004). Besides food production, PUA also enriches the social and ecological values of agriculture, including the rural landscapes (OrtizMiranda, Pérez, \& Faus, 2010) and cultural identity of the rural idyll (Hoggart \& Paniagua, 2001). Generally, PUA addresses a wider spectrum of production through multifunctional development (Wilson, 2007).

For PUA, the multifunctionality pinpoints the association between peri-urban and urban development. A high level of multifunctionality occurs at an advanced level of urban development (Wilson, 2007). Changes in the values of agricultural production, consumption and environmental protection are largely driven by changes in the urbanised world (Yang, Cai, Dunford, \& Webster, 2014). As Holmes (2006) argues, multifunctional agriculture arises for various reasons, including agricultural overcapacity, the emergence of alternative amenity-orientated uses and changing societal values, such as the valuation of biodiversity, ecological sustainability and social justice.

The multifunctional trend in agriculture has plenty of implications for urban and rural development. In contemporary society, agricultural depression has been observed in many regions (Hoggart \& Paniagua, 2001). Although it faces great pressure from urbanisation, agriculture is still essential to maintaining and promoting rural development with high added value by providing social and environmental goods. The OECD (1998) claims that 'beyond its primary function of supplying food and fibre, agricultural activity can also shape the landscape, provide environmental benefits such as land conservation, the sustainable management of renewable natural resources and the preservation of bio-diversity, and contribute to the socio-economic viability of many rural areas'. The multifunctional trend transforms conventional farming and enhances agriculture's vitality and contributes its social and environmental values to society. Thus, it connects agriculture and the development of modern cities.

Researchers often focus on food production and its related rural economy (Cole, Lee-Smith, \& Nasinyama, 2008, Lee-Smith, 2010), downplaying the social and environmental aspects and neglecting the significance of rural-urban interactions in determining PUA opportunity and performance (Ellis \& Sumberg, 1998). Although the roles of multifunctional agriculture are often a topic for European rural and agricultural policy, who can benefit from it and how are seldom discussed (McCarthy, 2005). Also, with the multifunctional transition, farmers face increasing uncertainties and complexities of economic diversification (Hoggart \& Paniagua, 2001). It remains a big step forward to innovate farming in rural development and translate the multifunctional discourses into concrete, implementable policies (Clark, 2006; Marsden \& Sonnino, 2008). 


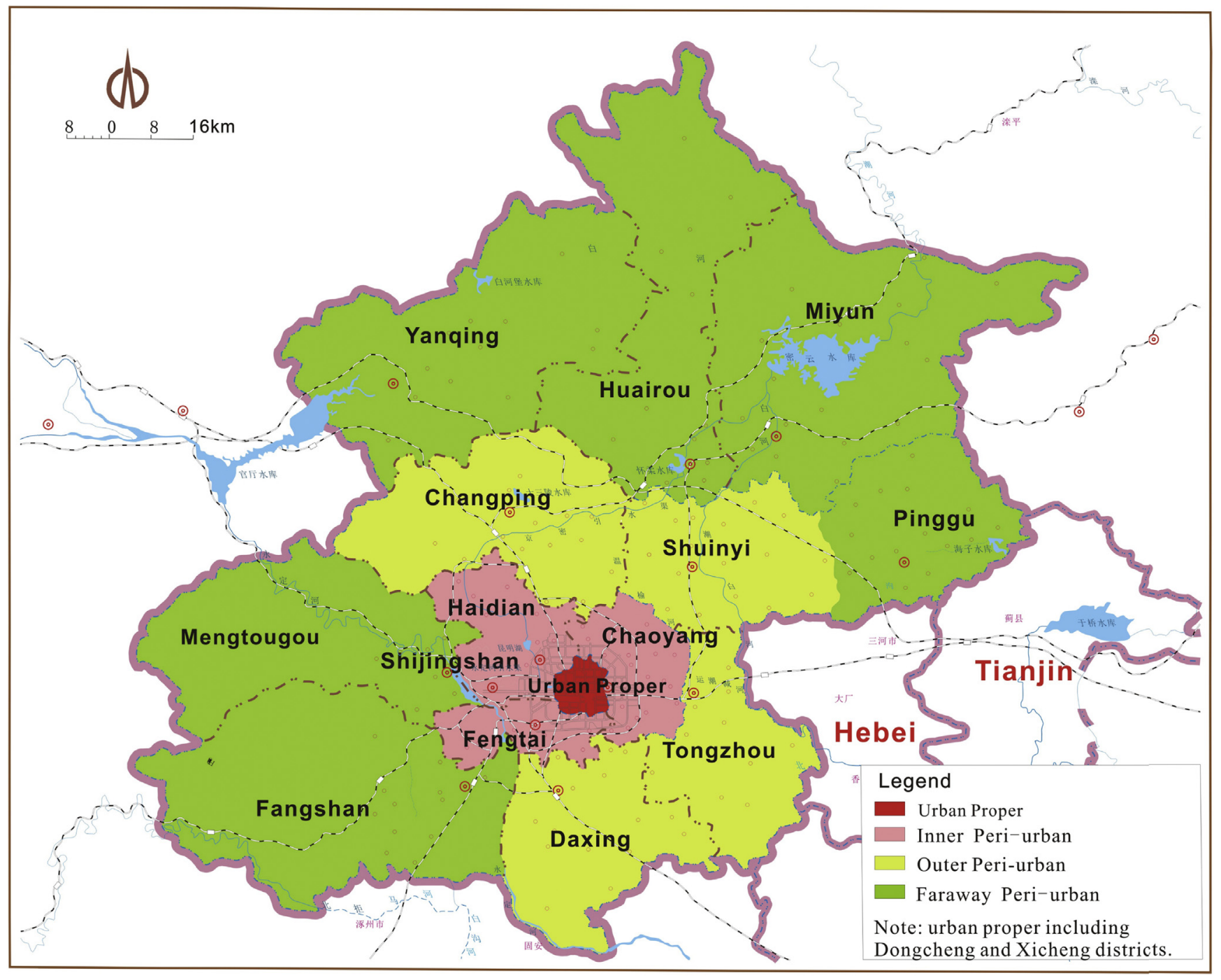

Fig. 1. Map of Beijing municipality.

As Zasada (2011) points out, multifunctionality creates opportunities to meet the large, growing urban demand for goods and services, which enriches agriculture near cities and calls for new planning and policy approaches.

As PUA activities involve local innovations in urban and agricultural sectors, it is important to consider them when making agricultural policies and planning cities. Relevant efforts have been made in some countries; for example, there was the 'food charter' that pursued a sustainable food system in Bingham (Hardman \& Larkham, 2014) and a call for a participatory and representative system to ensure UA development in New York (Cohen \& Reynolds, 2014). Endeavours are still needed to explore the policy implications of these new activities and enhance urban and rural connections (Dubbeling, 2014). In particular, many issues are still unclear; for instance, how could PUA be properly addressed in agricultural and urban policies? What is the added value if PUA is incorporated into urban policies? How could policy makers manage the growth of PUA activities?

\section{PUA development in Beijing}

Beijing has witnessed various new forms of economic activity through the specialisation and diversification of traditional agriculture. Such PUA, mostly initiated by local residents, has important implications for Beijing's rapid urbanisation. According to economic activities and key players in PUA, the main activities can include: agro-tourism, enterprise-based food processing, high-tech agro-enterprises/agro-parks and farmer collective activities.

\subsection{Agro-tourism}

Agro-tourism is perhaps the earliest and most popular form of PUA activity in Beijing. There are two major types: Farmerhousehold-based sightseeing agriculture (FHSA), which invites participants to do simple farm work; and enterprise-based recreational agriculture parks (ERAP), which provide larger-scale, sophisticated recreational facilities for observing and experiencing complex agricultural activities. While FHSA is primarily based on farmland and home-stays, ERAP provides off-farm activities and higher-quality accommodation (Figs. 2 and 3). ERAP often creates finer design and modern functions through larger investments and a higher level of commercialisation.

As Figs. 4 and 5 demonstrate, FHSA and ERAP prevail in periurban Beijing. Both types tend to be distributed near bodies of water and mountainous areas to take advantage of the natural scenery. They also tend to be concentrated along expressways to benefit from better city access.

The rapid development of agro-tourism is reflected in the 
increase in FHSA and ERAP facilities and related jobs (Table 1). As awareness has grown, PUA has gained popularity among Beijing urbanites. Both FHSA and ERAP facilities doubled their visitor numbers and tripled their revenues from 2005 to 2014.

FHSA activities are easy for individual rural households to commence. Typically, visitors view different crops, pick vegetables and fruits, and make local dishes with freshly harvested produce. Host families renovate rooms in their own homes for guest accommodation. By comparison, ERAP activities are on a much larger scale, though some ERAP resorts started as FHSA facilities. ERAP developments need much larger investment, more staff and are often in a more established tourism area. For instance, boutique hotels and restaurants are often established within the parks (Fig. 3). They are also more responsive to new customer requirements.

Xiedao ('Crab Island') Green Resort (XGR) is a typical ERAP (est. 1994), covering 180 ha. It was partly built on a piece of idle land, where a high-voltage power supply for the Beijing Capital Airport traverses the area underground (Fig. 6). Through extensive renovation, the land was developed with a pond and a crab-shaped island in the centre. XGR provides visitors with multiple services, including accommodation, catering and recreational programmes. It also maintains farming and agro-processing activities. It currently occupies all the land of one village and is expanding to neighbouring villages. According to the manager, tourism activities take up only $10 \%$ of the resort's land, but generate $90 \%$ of the gross profit (interview with the General Manager, Mr. Fu, of Xiedao in 2005).

\subsection{Enterprise-based food processing}

Since agriculture is strictly controlled by the state, private investments used to be very limited. In 2008 , nearly 4000 private firms were engaged in agriculture, providing jobs for 35,000 people in Beijing. Among these, the number of agro-production and processing firms amounted to 940, generating RMB 25 billion annually. One large firm, the Mutual Benefit Food Group (MBFG), was founded in 1993 by a Chinese entrepreneur returned from Canada. Its number of employees rose from only 3 to 1700 between 1993 and 2003. Its annual production value is over RMB 200 million and its profit was RMB 17 million in 2003. MBFG takes a 1/3 share of the national market in calcium-rich food and a $1 / 4$ share of the national market in honey production. It also leads the production and sale of lotus root powder in China. Currently it has 4 production bases, 8 affiliated corporations, 24 sales outlets and 6 overseas sales agencies. Three of its production bases are in Miyun in peri-urban Beijing (Fig. 7) and one is in Baoying County of Jiangsu Province; its headquarters are located in central Beijing.

\subsection{High-tech agro-enterprises/agro-parks}

With the modernisation of Beijing, there are increasing opportunities to apply high technology in agricultural development. According to the Beijing Municipal Agricultural Bureau, Beijing accommodated 375 high-tech agro-parks covering 15.7 ha by 2003 . These agro-parks usually enjoy preferable taxation waivers or deductions for three to five years. Most parks are government initiated, such as Xiaotangshan (XTS) National Agricultural Demonstration Park and Shunxin Agricultural Park. XTS produces orchids for markets in Taiwan and Mainland China.

Some other parks were initiated by private companies and gradually gained recognition and support from the government, such as Tongzhou International Urban Agriculture High-Tech Park (TIUAHTP). TIUAHTP was founded in 2009, located in Lucheng Town in east Beijing. The founder is a professor from China Agriculture University. The park occupies about 6670 square meters. Its main products are seeds, agricultural equipment and technological services. With successful lobbying, TIUAHTAP gained RMB 2 million from Tongzhou District Government to construct its first instalment. The site is divided into three areas: the agro-technology demonstration area (including greenhouse agriculture, new vegetable seeds and a picking area); the agro-technology research and development area (including a cold-chain logistic centre, aqua technology centre, and seed and tissue cultivation centre) and the office and service area. Taking advantage of its close connection with China Agriculture University, TIUAHTAP works to commercialise agro-related patents and techniques developed by university researchers. It also showcases new products and technologies (Fig. 8).

\subsection{Farmer collective activities}

Farmers' cooperative organizations are another important form of PUA development. In 2008, Beijing had 1273 farmer cooperatives and 77 agricultural cooperatives (nongye hezuoshe). These cooperatives have enrolled around 298,000 household members. Most of them are non-governmental organisations, but they act as nexuses for the government to guide agricultural production to meet market requirements.

Green Fruit and Vegetable Cooperative (GFVC) is a typical farmer cooperative, established by a small group of farmers in 2000. It has expanded to enrol 168 household members. It focuses on the production of grapes, cherries and mushrooms, responding to market demands for fresh fruits and fungi in Beijing. China Agriculture University and Chinese Academy of Agriculture Science provide seeds and quality control. The two institutions also provide training courses for cooperative members (Fig. 9). The cooperative
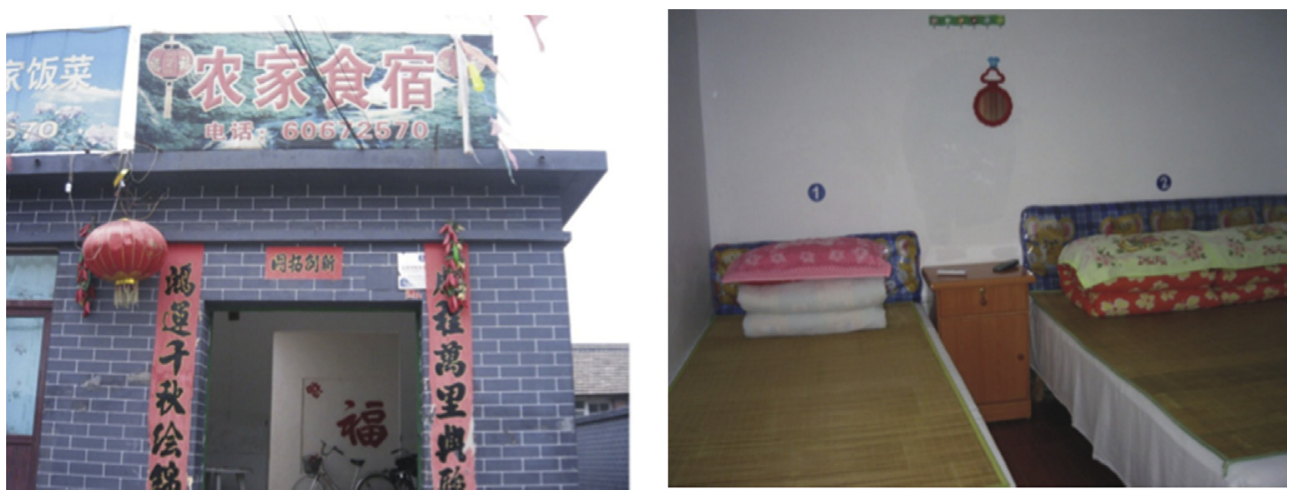

Fig. 2. Examples of farmer-household-based sightseeing agriculture (FHSA) accommodation in Beijing (author's photos). 

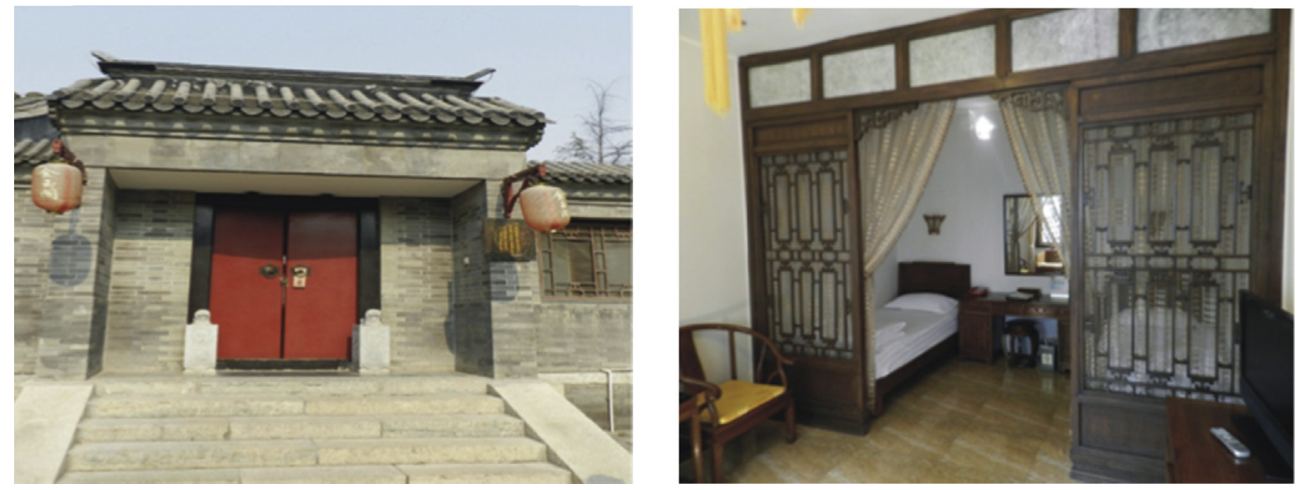

Fig. 3. Examples of enterprise-based recreational agro-park (ERAP) accommodations in Xiedao (author's photos).

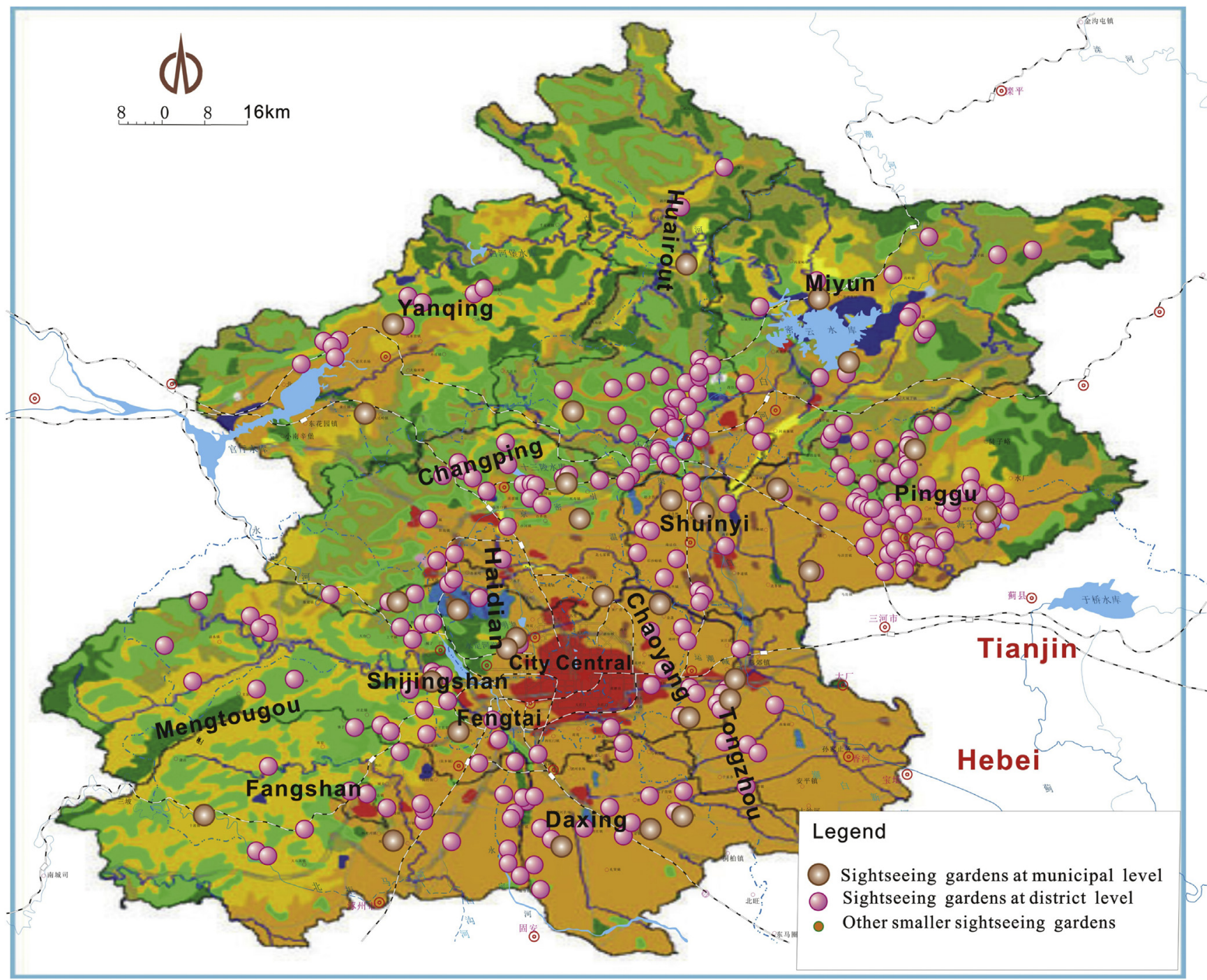

Fig. 4. Distribution of FHSA in Beijing.

(Source: Author, based on material provided by the Beijing Agricultural Committee)

provides seeds and technological support to its members. A low membership fee is charged for management, training and consultancy. With the help of the cooperative, member households sell mushrooms directly to hotels in the urban centre and restaurants in agro-tourism parks at a price 8 to 10 times higher than the standard wholesale price.

\section{Reflections and policy implications}

\subsection{Varied forms of peri-urban agriculture}

There is no clear and uniform definition of PUA owing to its multifunctionality. Marsden and Sonnino (2008) outline three 


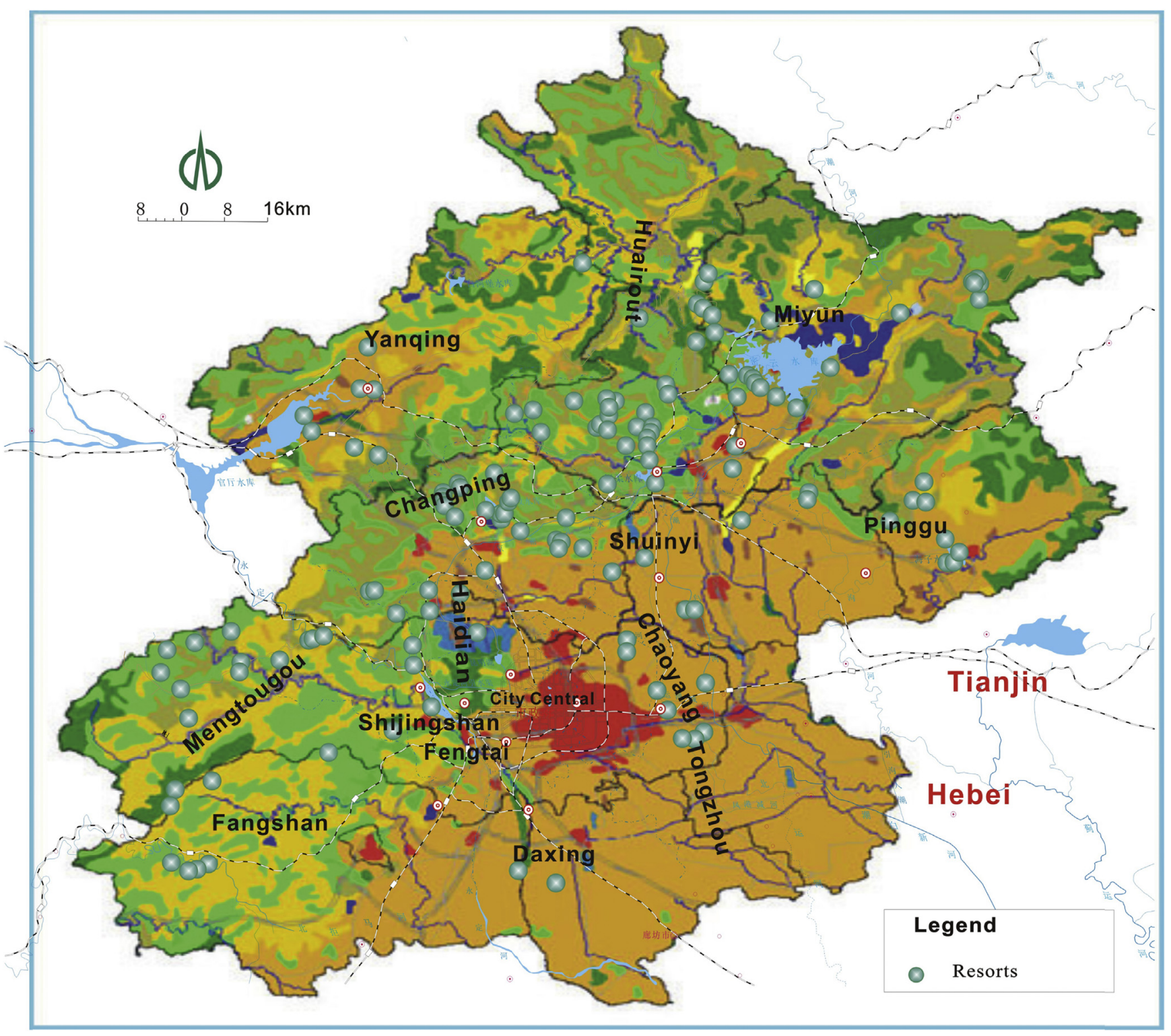

Fig. 5. Distribution of ERAP in Beijing.

(Source: Author, based on data provided by the Beijing Agricultural Committee)

Table 1

Development of agro-tourism in Beijing.

\begin{tabular}{|c|c|c|c|c|c|c|}
\hline & \multicolumn{3}{|l|}{ FHSA } & \multicolumn{3}{|l|}{ ERAP } \\
\hline & 2005 & 2014 & Increase & 2005 & 2014 & Increase \\
\hline Number & 7268 & 8863 & $22 \%$ & 1012 & 1301 & $29 \%$ \\
\hline Employment & 14,070 & 21,493 & $53 \%$ & 40,729 & 47,088 & $16 \%$ \\
\hline Number of visitors (,000 person-times) & 7589 & 19,142 & $152 \%$ & 8925 & 19,112 & $114 \%$ \\
\hline Revenue (Million RMB) & 314 & 1125 & $258 \%$ & 788 & 2492 & $216 \%$ \\
\hline
\end{tabular}

Sources: Beijing Agricultural Bureau and Beijing Statistic Year Book, 2015

development paradigms of multifunctional agriculture in shaping UK and European rural spaces and policies: diversification as a survival strategy for famers, introducing spatial regulations for a consumption countryside, and promoting sustainable rural development. Our research is in line with these paradigms, substantiating three key issues of multifunctional agriculture raised by the authors:
It must add income and employment opportunities to the agricultural sector; it must contribute to the construction of a new agricultural sector that corresponds to the needs and expectations of the society at large; it must imply a radical redefinition and reconfiguration of rural resources, to varying degrees, in and beyond the farm enterprise. (p. 423) 

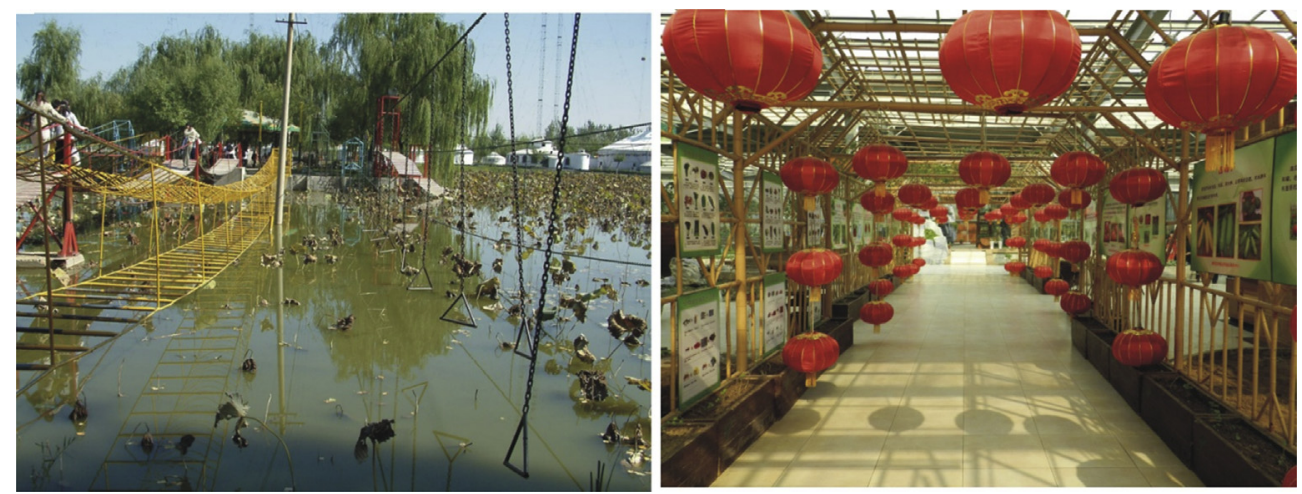

Fig. 6. Xiedao Green Resort (XGR): Outdoor activities (left) and interior design (right) (author's photos).
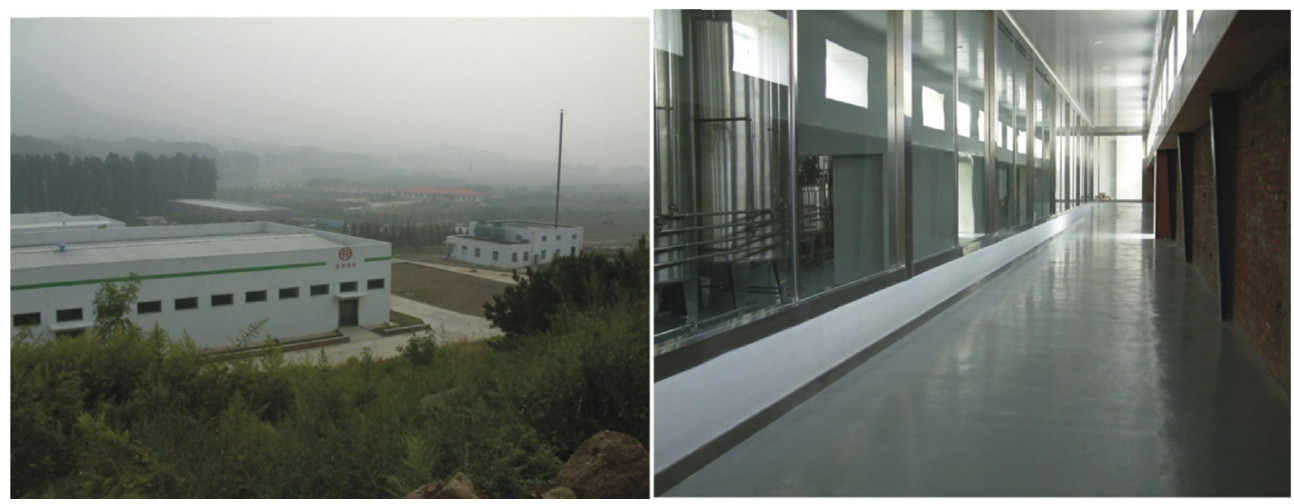

Fig. 7. Mutual Benefit Food Group production base in Miyun County (author's photos).

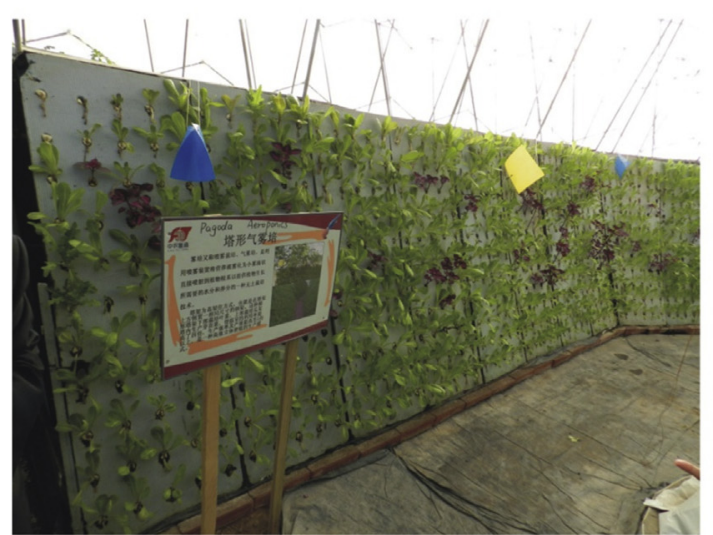

Aeroponics

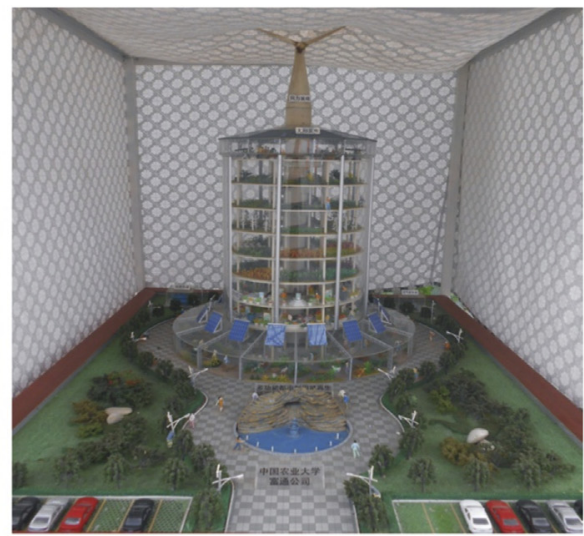

A sightseeing tower with

stereo-cultivation (design)

Fig. 8. Tongzhou International Urban Agriculture High-Tech Park (author's photos).

Chinese PUA can be considered as a mechanism for developing the interface between rural and urban areas. Policy interventions, such as basic arable land protection, are sometimes the strongest measures for conserving farming activities. However, farmers and the agricultural sector are still disadvantaged and vulnerable. Multifunctional forms, such as agro-tourism, provide a 'survival' strategy, allowing entrance into diverse markets and increased economic returns. This strategy caters to the new consumption requirements of urbanites, who are increasingly concerned with food quality and the social and environmental values of peri-urban rural areas (van Veenhuizen, 2006). Under PUA, modern management methods are introduced to improve agricultural efficiency (Morgan, Marsden, Miele, \& Morley, 2010), and rural resources are redefined and reconfigured to facilitate urban social, economic and environmental dynamics (La Rosa, Barbarossa, Privitera, \& Martinico, 2014). PUA provides green food, creates social and recreational spaces, and alleviates environmental degradation from urban expansion.

The Beijing example shows PUA emerged and was transformed through the multifunctionalization of agriculture, from producing agricultural products to industrial customized food and social/ recreational services. The multiple PUA forms have a threefold 


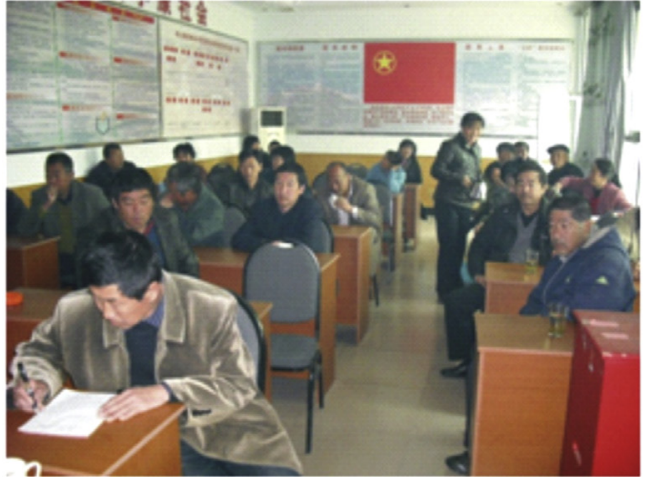

Training class for planting mushroom in Jan of 2009

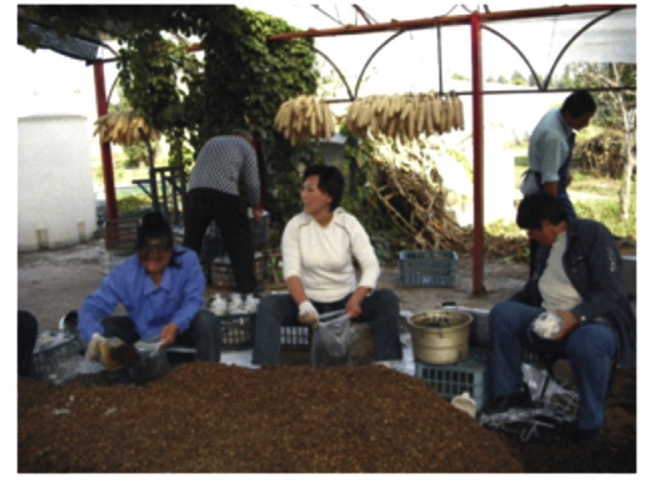

Working together of the cooperative members

Fig. 9. Green Fruit and Vegetable Cooperative: Training and working (Photographs by X. Zan).

significance. First, they include a large variety of activities, such as agro-tourism, agro-production and high-tech agriculture. Second, different PUA activities are associated with different land uses. For instance, land for agro-tourism is mainly used for recreation and entertainment, while high-tech agriculture is situated in parks, where cooperation, learning and dissemination of agro-techniques are facilitated. Third, different PUA facilities can be operated by different stakeholders, such as farmers, farmer-cooperatives, enterprises and agro-park authorities. These constitute the basic characteristics of PUA that are distinct from traditional agriculture. Focusing on each specific form of PUA, it is easier to address the emerging sector in policy making to promote its development and integrate its varied new forms of economy into the existing context.

\subsection{Local PUA innovations}

Aspects crucial to the success of local PUA initiatives in Beijing include entrepreneurship, integrating clean green production with natural resource management, marketing, specialisation, diversification, and business organisations.

\section{(1) Entrepreneurship}

PUA entrepreneurs are not necessarily farmers. Some were once engaged in other industries, and some have overseas experience. This is contrary to the conventional image of agriculture and the divided urban and rural economies of China. With broader horizons, sophisticated knowledge and managerial experience, these entrepreneurs introduce new ideas and technology to agriculture, and extend the industrial chain towards diversification. Most are enthusiastic about agriculture despite their urban background:

I used to be an agro-technician in a village and started my own business from a small factory producing construction materials. I like agriculture and my agro-business suffered a difficult time during 1991-1994, but I seized the opportunity when I found people like to escape the city and come here for fishing and other activities. (Mr. Fu, General Manager of XRG)

I obtained my bachelor's degree in Canada but I wanted to return to China to start up an agro-business because my parents were farmers. I knew there was a big potential for the food industry given the huge population in China. (Mr. Yin, CEO of MBFG)

We were indigenous farmers here. Although we farmed year by year, we knew little about the demand from the urban market. In 1996 , when we participated in a two-year study program organized by the China Grape Association (Beijing Branch), we learned that fresh fruits were very valuable. After we returned to Huairou, we rented $20 \mathrm{mu}$ (about $1.3 \mathrm{ha}$ ) of land and built five greenhouses to grow 17 new varieties of grapes. ... It would be good for us to share market information and agro-technologies, to valorise our products, and to expand our market. Therefore, we established this cooperative. (Mrs. Zan, member of GFVC)

(2) Integrating clean green production with natural resource
management

Chinese rural areas are generally seen as dirty and disorderly. Moreover, food safety has become a major concern, with contamination being a serious problem. Altering this stereotype is important for attracting people to participate in PUA and enjoy its agroproducts.

We make steamed dumplings with fresh vegetables directly picked from our field and fresh eggs. Although we have such dishes every day, the taste is different and much better than those on the tables of urban families. Our customers feel happy about breathing fresh air, visiting idyllic landscapes, picking strawberries and tomatoes, and having genuine rural family dishes (nongjia cai). (Mr. Fu, General Manager of

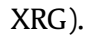

\section{(3) Marketing}

PUA farmers tend to be enthusiastic, proud of their businesses, and capable of promoting their products and services. For example, the owners of GFVC are very active in attending various workshops and presenting their business experience and progress. MBFG has its sales and management headquarters in Chongwenmen in central Beijing, and XGR established three sales offices in urban neighbourhoods. PUA enterprises also hold or sponsor various food festivals every year, such as the 2013 Beer Festival hosted by XGR.

\section{(4) Specialisation and diversification}

Food companies are eager to extend their business to agrotourism to tap into the expanding market. For example, MBFG developed an agro-tourism programme that includes field visits and simple food processing. XGR has its own crop fields, brewery and snack workshop. It also demonstrates the latest agricultural technologies for educational and research purposes.

\section{(5) Business organisations}

Enterprises and farmer collectives are major players who initiate PUA, which is different from household-based production. They 
make agricultural production and management more open. New technologies in both production and communication make it easier to respond quickly to the changing urban market. For example, XGR rented 3000 square meters of land in Inner Mongolia to provide fresh food to its park because of the sharply increasing number of visitors. TIUAHTP is heavily engaged in innovating agricultural technologies in collaboration with China Agricultural University. HVC has recently changed from growing grapes to growing vegetables and mushrooms because of greater demand from Beijing residents and the larger profit margin.

\subsection{Economic impact}

The economic impact of PUA is positive and significant. Compared with traditional agriculture, PUA provides job opportunities for local and migrant farmers and raises their income. At the agricultural production base of MBFG there are 1210 employees, 900 of whom are directly engaged in agricultural production. Over 1000 positions are filled by laid-off workers and low-income farmers. Around 400 of XGR's 1200 employees are engaged in agricultural production and services, and around 800 in catering, management and other positions. Table 2 illustrates the income levels of PUA employees. According to the Beijing Statistics Bureau, the average income of a farmer family was about RMB 12,161 per capita in 2012, among which only RMB 731 came directly from farming. Owing to the high added value created by PUA activities, farmland is better protected and utilized. With more visitors to peri-urban areas, restaurants and other commercial outlets are emerging around PUA resorts (Fig. 10).

Source: Author.

Although promising, PUA development faces many challenges. Nearly all of the entrepreneurs we interviewed expressed that financial constraints are the biggest problem for improving food safety and the quality of service facilities. In China, obtaining a bank loan is difficult for small and non-state enterprises. Besides, the urban market is changing and PUA enterprises need to compete with farmers both inside and outside Beijing. Customers require a stable supply, but there is great uncertainty in agricultural production. Most farmer participants and investors in PUA are attracted to short-term revenues and are reluctant to make long-term investments. This makes it difficult for PUA enterprises and farmer collectives to accumulate capital and deal with risks.

\subsection{Social impact}

PUA not only creates jobs and revenue, but also generates new business opportunities and improves local infrastructure and services. For example, $10 \%$ of the tax on MBFG is used for local road construction and primary education. Some enterprises, like XGR, donate part of their revenue to the construction of roads and schools in their village. Besides, with the establishment of XGR, new restaurants and two new bus lines leading to the city centre were developed. In addition, PUA also promotes agricultural training and education. Child and adult visitors can gain agricultural knowledge while picking fruits and vegetables (Fig. 11) and attending workshops. From 2009 to 2013, over 60 workshops and summer school programmes were held at TIUAHTP.

For farmers who are struggling but have a strong attachment to farming, PUA provides an alternative to urban jobs. A middle-aged woman working for MBFG said she could not bear to abandon farming. She works for MBFG in the daytime and takes care of her own farmland at dawn, which provides an income comparable to that of an urban job. PUA is usually more attractive to rural migrants rather than local farmers (Pu \& Tang, 2015), who prefer to work in factories because of the higher income (Yang, Cai, Qi, Liu, \&
Deng, 2015). We found that approximately 450 out of 800 local villagers aged $18-50$ work in the urban centre. More than 300 locals work in clothing and sandalwood factories in the village. Only around 20 local villagers are employed by MBFG. Young villagers are reluctant to work for MBFG since they could get a 25\% higher income working at a local factory.

Consequently, employees of PUA enterprises are mostly migrant farmers. In our survey, $80 \%$ of XGR employees and $90 \%$ of MBFG employees were migrants. This is in line with the fact that about $90 \%$ of the population in peri-urban Beijing are migrants, according to the Beijing Statistical Bureau (2011). One young male worker at XGR said:

I am from Henan province. I moved here one year ago and signed a three-year contract with the company. Because of the high living cost in Beijing, our children are taken care of by their grandparents in our hometown, but I can earn a salary which is five times higher than what could be earned in my hometown. (Interviewed at XGR in 2011)

\subsection{Environmental concerns}

PUA practitioners are generally more aware of the ecological value of the natural environment than local farmers or industrial workers. For example, XGR recycles wastes and turns them into fertilizer. A waste water works and two marsh-gas ponds have been built to generate clean water and electricity for the hotels and restaurants (Yang et al., 2010). XGR also began recycling sewage and solid waste from the surrounding communities. Recycled water accounts for one-third of the total water usage, and almost half of the power used in the park is self-generated. The local communities are saved the cost of waste collection. Eventually the local environmental condition can be significantly improved without government intervention.

Other environmental improvements are noticeable. Typically, Chinese farmland is somewhat contaminated due to overuse of insecticides and fertilizers. However, a clean, organic way of farming is required to produce green food for PUA, which leads to less chemical contamination. Moreover, as PUA resorts provide fruit and vegetable picking activities, farmland is kept in a clean, orderly manner. Farming and farmland thus become more appealing to visitors from the city. This also benefits local farmers as they have a comfortable living and working environment. Only a short distance away from urban areas, PUA resorts have turned traditional periurban rural sites into green backyards of the city. The reason is perhaps the synergy effect between ecologically friendly environment and economic returns, as the General Manager of XGR said 'Good environment is the premise that we can attract visitors, which is the precondition that all other services and facilities in our park can be consumed and appreciated'.

In general, each type of PUA contributes to one or several particular functions. Enterprises-based food processing firms shorten the industry chain and transportation distances in the provision of freshly processed food to local tables. Therefore, PUA, to some extent, enhances the nutrition status and health of local citizens. Agro-parks promote technological innovation in agricultural production by providing a major platform for attracting capital investment in agriculture and enabling effective communication and cooperation between firms. Farmer cooperatives facilitate collective farming activities, which are particularly important for protecting farmers' interest, as they are increasingly vulnerable in the market economy. Agro-tourism creates opportunities for local citizens to temporarily escape from the stressful city life and enjoy relaxing and unsophisticated 
Table 2

Monthly salary of peri-urban agriculture (PUA) employees (in RMB, 2011).

\begin{tabular}{|c|c|c|c|c|}
\hline PUA & $\begin{array}{l}\text { MBFG (Agro-processing } \\
\text { enterprise) }\end{array}$ & $\begin{array}{l}\text { XGR (Agro-tourism } \\
\text { park) }\end{array}$ & $\begin{array}{l}\text { TIUAHTP (High tech } \\
\text { agriculture) }\end{array}$ & GFVC (Agro-production collective) \\
\hline $\begin{array}{l}\text { Mid-level } \\
\text { managers }\end{array}$ & $5-6000$ & $5-7000$ & $7-8000$ & $\begin{array}{l}60 \% \text { higher than working individually, and } 2-3 \text { times higher than } \\
\text { traditional farming }\end{array}$ \\
\hline Technicians & $3-3500$ & 3000 & $3-4000$ & \\
\hline Workers & 2500 & $2-3000$ & 3000 & \\
\hline
\end{tabular}

Source: Survey by authors in 2011.

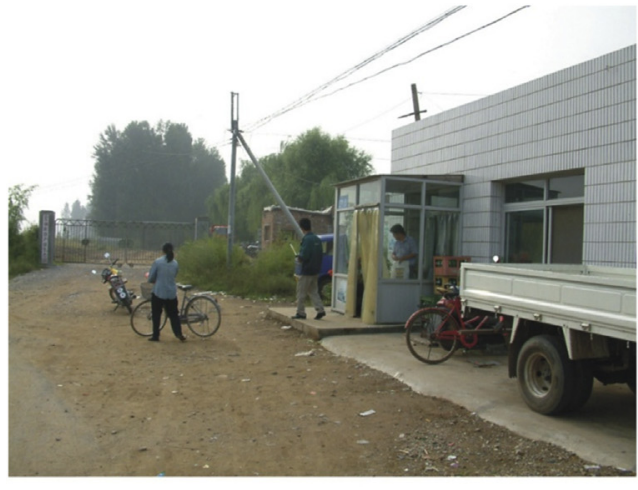

Kiosksnack in front of MBFG

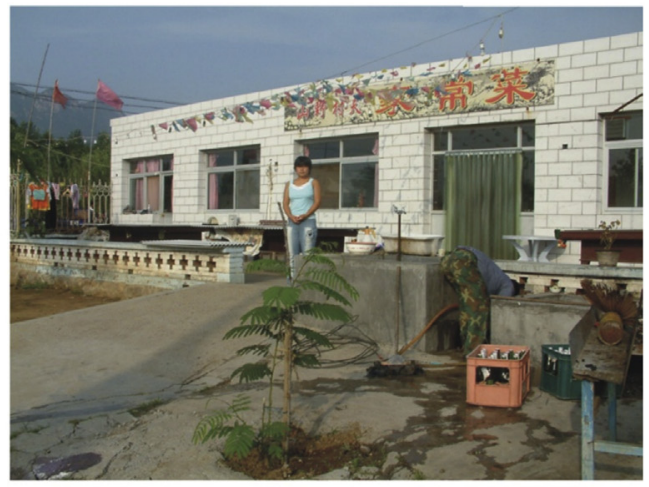

A small restaurant close to $\mathrm{MBFG}$

Fig. 10. Small businesses near a PUA resort
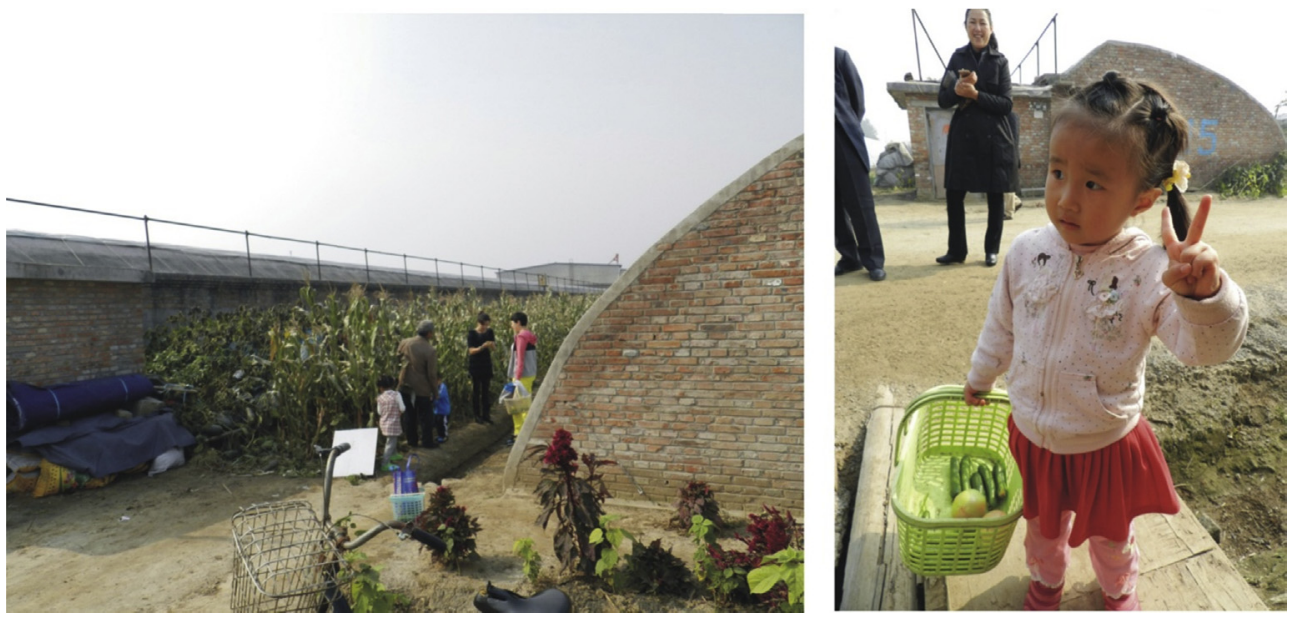

Fig. 11. Children learning about farming at XGR.

agricultural activities in the natural environment. These functions, by exploiting the social and environmental values of PUA, have considerably strengthened the economic competitiveness of the agricultural sector.

\subsection{Planning implications}

Given its impact and popularity, PUA has been frequently addressed by policy makers. Beijing launched the so-called '2-2-1 action programme' in 2004, aimed at promoting the utilization of two fundamentals, agro-oriented resources and the market; two inputs, capital and technology; and an information platform. The programme was built upon the strength of Beijing, where 13 of China's top 20 agro-related institutes and universities are located.

To organize the spatial distribution of PUA development at the city scale, the Beijing Urban Agricultural Policy introduced in 2006 outlined a PUA zoning plan (based on interviews with the Recreational Agricultural Commission of Beijing in 2006). Four PUA development areas were designated to coordinate with general city development plans (Fig. 12). The city government intends to use PUA to better integrate urban and rural development to: (1) improve food quality for the growing urban population; (2) maintain social stability by creating rural employment and increasing rural income; (3) improve rural and urban environments by reducing dust and the heat island effect; (4) establish an effective water management and recycling system; and (5) integrate agriculture into urban planning to use urban and peri-urban land more efficiently.

However, some critical issues make it difficult to incorporate PUA development into urban planning and policy. One is the barrier 
entailed by land use regulations. PUA resorts require land to build facilities in peri-urban rural areas, which are not necessarily designated as built-up areas. Moreover, both the built-up land and fields for PUA involve collective rural land with ambiguous property rights, which hinders large-scale land configuration and discourages long-term investments. To some extent, some innovative agricultural practices in the Pearl River Delta (PRD) in China may provide a good reference for overcoming such barriers in the longer term. The greenway planning and its systematic implementation in the PRD facilitate the integration between urban and rural areas (Qiu, 2011). It also enables the rural sector to diversify its functional structure to include agro-tourism through the construction of relevant facilities and infrastructure along the greenways. Nevertheless, whether an approach that is successfully implemented in city conurbations at the regional level can be applied to a municipality remains a question to be examined.

\section{Conclusions}

Traditional agriculture is under unprecedented pressure in the rapid urbanisation era. This paper presented some alternative approaches to agricultural development in peri-urban areas. Based on an empirical study in Beijing, we explored major types of PUA development, including food processing, agro-tourism, high-tech agriculture, and farmer collectives.

The findings showed positive outcomes in economic, social and environmental aspects. With increasing economic returns, PUA enhances the profitability of the agricultural sector. It also offers an instrument for local governments to balance out the strict use control over rural land and the need for economic growth. It slows down the process of agricultural land loss and ensures an adequate food supply for the growing urban population. As a supplement to traditional urban and agricultural sectors, PUA provides additional employment for low-skill rural migrants. It thus consolidates the peri-urban areas of Beijing as a cushion to relieve the pressure of in- flow migration on the over-populated urban districts. Besides, PUA also serves as an ecological buffer, mitigating the environmental impact of urban expansion. These positive roles and outcomes have attracted the attention of policy makers and raised PUA on the policy agenda.

Our investigation stressed the importance of multifunctionality and diversity in agricultural development literature. The varied forms of PUA connect the urban and rural hemispheres in economic, social and ecological dimensions. The pursuit of sustainable development policies by the government can thus be inspired to seek a more integrated mode of development between urban and rural sectors. Moreover, different from previous top-down approaches that aimed to transform agriculture but were ineffective, bottom-up local initiatives are key in the development of PUA. Here, the Beijing municipal government is a pioneer that has recognized those local initiatives and tried to facilitate them and integrate their PUA developments into city development plans. However, to facilitate PUA development further, reform measures should be taken to allow land rights to be transferred from rural collectives to PUA enterprises or organizations like the case in the PRD, to provide more financial support to PUA enterprises/practitioners, and to further improve the economic status and social security of migrant workers involved in PUA.

We also found that Chinese PUA resembles neither the African nor European models. Instead, it is largely contextualized by China's current urban transition featuring rapid urban expansion, massive-scale rural-urban migration, and the upgrading and transformation of the economy. Its development is subject to the state of the local economy and society in both urban and rural areas. While PUA practices and innovations in Beijing has been examined in this study, other forms and practices of PUA development require further research in the unique contexts of other Chinese cities.

Regarding limitations, because UA is quite a new theme, there are few datasets recording its economic, social and environmental performances. Ideally, regions should systematically survey and

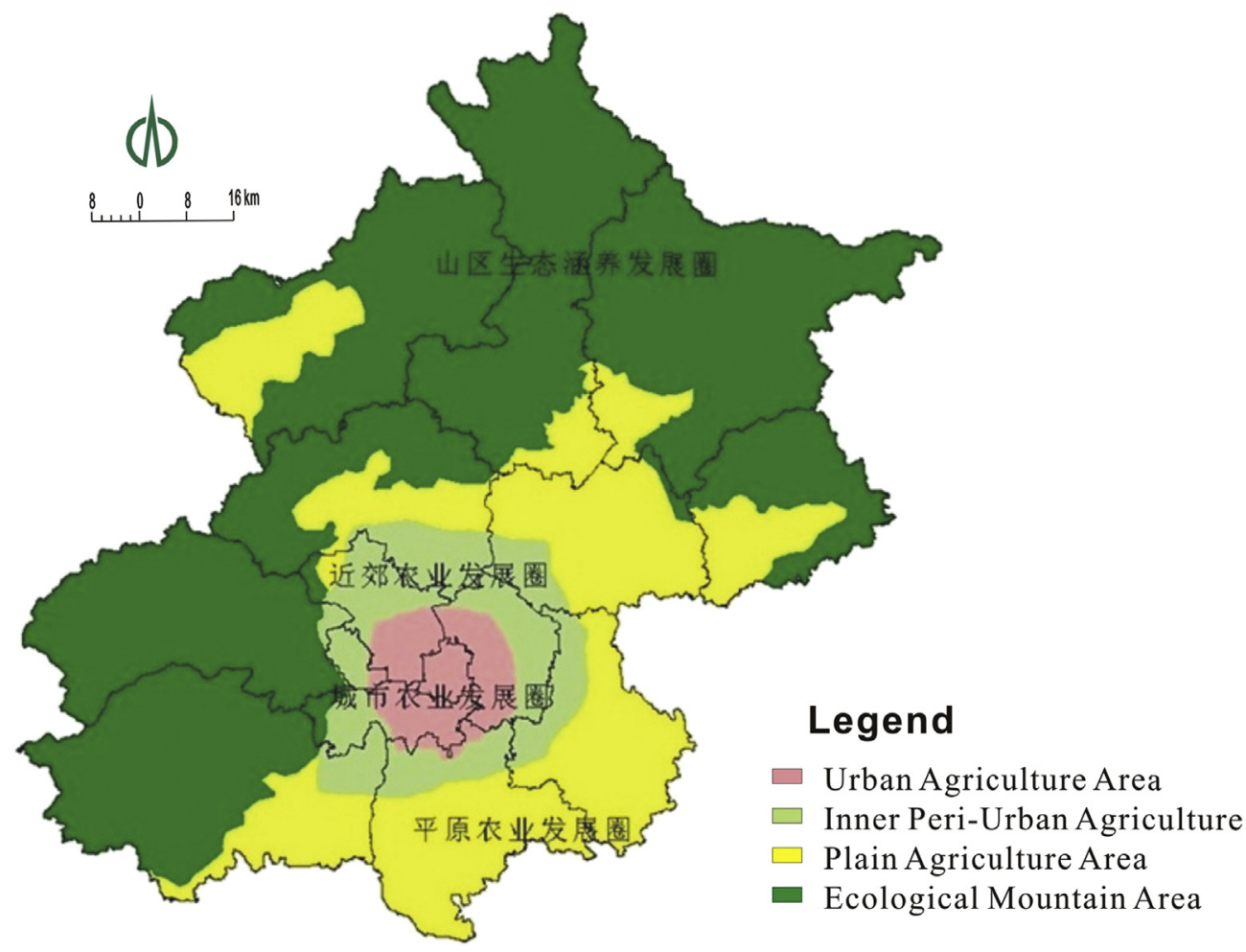

Fig. 12. Spatial zoning of PUA in Beijing (Source: 12th Five-year Plan of Agriculture in Beijing). 
document UA. Employing field study, this paper mainly identified and analyzed the value of PUA in improving the economic, social and environmental functionalities of agriculture. In-depth analysis is needed to investigate responses and linkages with urban sectors in order to fulfil the goal of integrated urban-rural development and build a better design for such a plan.

\section{Acknowledgement}

The research is sponsored by a grant of the Natural Sciences
Foundation of China (No. 41530751), Early Career Talent Program of Chinese Academy of Sciences 'Youth Innovation Promotion Association of Chinese Academy of Sciences' (2014042), and China Scholarship Council (201504910654). The authors would also especially thank two anonymous reviewers for their very insightful and constructive comments.

\section{Appendix 1. Interviews on PUA in Beijing}

\begin{tabular}{lll}
\hline Type of PUA & Investigation [time] & Interviewees \\
\hline Agro-tourism & $\begin{array}{l}\text { Xiedao Green Resort } \\
{[2004-2008,2012-2013]}\end{array}$ & The general manager
\end{tabular}

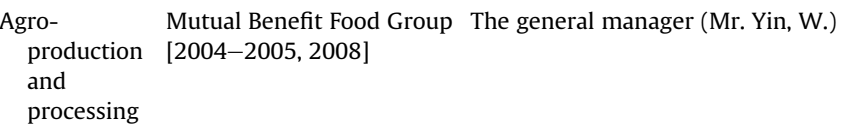

Assistant to the general manager (Ms. Gao); Sales manager;

Public relations manager
Assistant to the general manager (Ms. Gao): Director of plants A and B
Key questions

1. Are you a farmer? Why and how did you establish your company?

2. What are your major products and services?

3. How do you sell your products and services, and who are your main customers?

4. How does your company perform? How many employees do you have? How much land do you occupy? What is your revenue?

5. Where are your workers from and how much do they get paid?

6. Do you have any problems with the running of the company?

7. What's your plan for the future?

1. Where are you from? What was your major? And why did you join this company?

2. What do you think of the company's performance?

3. Where are your workers from and how much do they get paid?

4. Are you satisfied with your payment? And are the other workers satisfied?

5. Do you have any problems/expectations working here?

Employees $(n=11)$, including receptionists $(n=2)$, room 1 . Where are you from? What is your education? And why did cleaners $(n=4)$, restaurant waiters $(n=2)$ and crop workers $(n=3)$

2. How much do they pay? And are you satisfied with your payment?

3. Where do you live? And what other subsidizations other than wages do you receive?

4. Do you have training and promotion opportunities?

5. Do you want to return to traditional agricultural production? Or other engagements?

1. Are you a farmer? Why and how did you establish your company?

2. What are your major products and services?

3. How do you sell your products and services, and who are your main customers?

4. How does your company perform? How many employees do you have? How much land do you occupy? And what is your revenue?

5. Where are your workers from and how much do they get paid?

6. Do you have any problems with the running of the company?

7. What's your plan for the future?

1. Where are you from? What was your major? And why did you join this company?

2. How does the company perform?

3. Where are your workers from and how much do they get paid?

4. Are you satisfied with your payment? And are the other workers satisfied?

5. Do you have any problems/expectations working here?

1. Where are you from? What is your education? And why did you join this company?

2. How much do they pay you? And are you satisfied with your payment?

3. Where do you live? And what other subsidizations other than wages do you receive?

4. Do you have training and promotion opportunities?

5. Do you want to return to traditional agricultural production? Or other engagements? 
(continued)

\begin{tabular}{|c|c|c|c|}
\hline Type of PUA & Investigation [time] & Interviewees & Key questions \\
\hline $\begin{array}{l}\text { High-tech } \\
\text { agriculture }\end{array}$ & $\begin{array}{l}\text { Tongzhou International } \\
\text { Urban Agriculture High } \\
\text { Tech Park } \\
{[2008,2010-2013]}\end{array}$ & The general manager & $\begin{array}{l}\text { 1. Are you a farmer? Why and how did you establish the park? } \\
\text { 2. What are the major products and services of the park? } \\
\text { 3. How do you sell your products and services, and who are } \\
\text { your main customers? } \\
\text { 4. How does your company perform? How many employees do } \\
\text { you have? How much land do you occupy? And what is your } \\
\text { revenue? } \\
\text { 5. Where are your workers from and how much do they get } \\
\text { paid? } \\
\text { 7. What's your plan for the future? }\end{array}$ \\
\hline $\begin{array}{l}\text { Farmer } \\
\text { collective }\end{array}$ & $\begin{array}{l}\text { Green Fruit and Vegetable } \\
\text { Cooperative, a farmer } \\
\text { cooperative } \\
{[2006-2010]}\end{array}$ & $\begin{array}{l}\text { The couple who started the cooperative (Mr. Zhao, S. and } \\
\text { Miss Zan, X.) }\end{array}$ & $\begin{array}{l}\text { 1. Why and how did you establish this cooperative? } \\
\text { 2. What are your major products and services? } \\
\text { 3. How do you sell your products and services, and who are } \\
\text { your main customers? } \\
\text { 4. Do you benefit from the cooperative and how much does it } \\
\text { differ from the traditional way of farming? } \\
\text { 5. How many farmers are involved and how do they join? } \\
\text { 6. Do you have any problems with the running of your } \\
\text { collective? } \\
\text { 7. What's your plan for the future? }\end{array}$ \\
\hline
\end{tabular}

\section{References}

Adeyemi, A. (2000). In U.S.D.o. Agriculture (Ed.), Urban agriculture: An abbreviated list of references and resource guide 2000. Beltsville.

Beijing Statistical Bureau. (2011). Beijing statistics yearbook, Beijing.

Beijing Statistical Bureau. (2013). Beijing statistics yearbook, Beijing.

Bezemer, D., \& Headey, D. (2008). Agriculture, development, and urban bias. World Development, 36, 1342-1364.

Bjørkhaug, H., \& Richards, C. A. (2008). Multifunctional agriculture in policy and practice? A comparative analysis of Norway and Australia. Journal of Rural Studies, 24, 98-111.

Broadway, M. (2009). Growing urban agriculture in North American cities: The example of Milwaukee. American Geographical Society's Focus on Geography, 52, $23-30$.

Buller, H., \& Morris, C. (2004). Growing goods: The market, the state, and sustainable food production. Environment and Planning A, 36, 1065-1084.

City Farmer. (2007). Europe and urban agriculture, urban agriculture notes.

Clark, J. (2006). The institutional limits to multifunctional agriculture: Subnational governance and regional systems of innovation. Environment and Planning C: Government and Policy, 24, 331-349.

Clark, J. R. A., Jones, A., Potter, C. A., \& Lobley, M. (1997). Conceptualising the evolution of the European Union's agri-environment policy: A discourse approach. Environment and Planning A, 29, 1869-1885.

Cohen, N., \& Reynolds, K. (2014). Urban agriculture policy making in New York's "New political spaces" Strategizing for a participatory and representative system. Journal of Planning Education and Research, 34, 221-234.

Cole, D., Lee-Smith, D., \& Nasinyama, G. (2008). Healthy city harvests: Generating evidence to guide policy on urban agriculture. Lima: Peru.

Daugstad, K. (2008). Negotiating landscape in rural tourism. Annals of Tourism Research, 35, 402-426.

De Zeeuw, H., Van Veenhuizen, R., \& Dubbeling, M. (2011). The role of urban agriculture in building resilient cities in developing countries. The Journal of Agricultural Science, 149, 153-163.

Dubbeling, M. (2014). Status and challenges for urban and peri-urban agriculture policy making, planning and design. In International symposium on urban and peri-urban horticulture in the century of cities: Lessons, challenges, opportunities 1021 (pp. 121-132)

Ellis, F., \& Sumberg, J. (1998). Food production, urban areas and policy responses. World Development, 26, 213-225.

Hamilton, A. J., Burry, K., Mok, H. F., Barker, S. F., Grove, J. R., \& Williamson, V. G. (2014). Give peas a chance? Urban agriculture in developing countries. A review. Agronomy for Sustainable Development, 34, 45-73.

Hao, P. (2012). Spatial evolution of urban villages in Shenzhen, NL.

Hardman, M., \& Larkham, P. J. (2014). The rise of the 'food charter': A mechanism to increase urban agriculture. Land Use Policy, 39, 400-402.

Higgins, B. (1956). The "Dualistic theory" of underdeveloped areas. Economic Development and Cultural Change, 4, 99-115.

Hoggart, K., \& Paniagua, A. (2001). What rural restructuring? Journal of Rural Studies, 17, $41-62$.

Holland, L. (2004). Diversity and connections in community gardens: A contribution to local sustainability. Local Environment, 9, 285-305.

Holmes, J. (2006). Impulses towards a multifunctional transition in rural Australia: Gaps in the research agenda. Journal of Rural Studies, 22, 142-160.

Jarosz, L. (2008). The city in the country: Growing alternative food networks in Metropolitan areas. Journal of Rural Studies, 24, 231-244.

La Rosa, D., Barbarossa, L., Privitera, R., \& Martinico, F. (2014). Agriculture and the city: A method for sustainable planning of new forms of agriculture in urban contexts. Land Use Policy, 41, 290-303.

Lee-Smith, D. (2010). Cities feeding people: An update on urban agriculture in equatorial Africa. Environment and Urbanization, 22, 483-499.

Lin, Y., \& De Meulder, B. (2012). A conceptual framework for the strategic urban project approach for the sustainable redevelopment of "villages in the city" in Guangzhou. Habitat International, 36, 380-387.

Marsden, T., \& Sonnino, R. (2008). Rural development and the regional state Denying multifunctional agriculture in the UK. Journal of Rural Studies, 24 422-431.

McCarthy, J. (2005). Rural geography: Multifunctional rural geographies - Reactionary or radical? Progress in Human Geography, 29, 773-782.

Milligan, C., Gatrell, A., \& Bingley, A. (2004). Cultivating health': Therapeutic landscapes and older people in northern England. Social Science \& Medicine, 58, 1781-1793.

Morgan, S. L., Marsden, T., Miele, M., \& Morley, A. (2010). Agricultural multifunctionality and farmers' entrepreneurial skills: A study of Tuscan and Welsh farmers. Journal of Rural Studies, 26, 116-129.

Mougeot, L. J. A. (2006). Growing better Cities: Urban agriculture for sustainable development, Ottawa.

OECD. (1998). Agricultural policies in OECD countries 1998: Volume I - Monitoring and evaluation (Vol. II). Paris: Measurement of Support and Background Information.

Ortiz-Miranda, D., Pérez, O. M. M., \& Faus, A. M. M. (2010). Innovative strategies of agricultural cooperatives in the framework of the new rural development paradigms: The case of the region of Valencia (Spain). Environment and Planning A, 42, 661-677.

Pu, H., \& Tang, S. (2015). Floating or settling down: The effect of rural landholdings on the settlement intention of rural migrants in urban China. Environment \& Planning A, 47, 1979.

Qiu, Q. (2011). Greenways connect Pearl River Delta cities. China Daily. http://www. chinadaily.com.cn/china/2011-05/11/content_12485701.htm.

Saifi, B., \& Drake, L. (2008). A coevolutionary model for promoting agricultural sustainability. Ecological Economics, 65, 24-34.

Shillington, L. J. (2008). Complex ecologies and city spaces: Social-ecological networks of urban agriculture. In M. Redwood (Ed.), Agriculture in urban planning: Generating livelihoods and food security (pp. 201-214).

Tan, M. (2014). The transition of farmland production functions in metropolitan areas in China. Sustainability, 6, 4028.

van Veenhuizen, R. (2006). Cities farming for the future, urban agriculture for green and productive cities.

Wilson, G. A. (2007). Multifunctional agriculture: A transition theory perspective.

Yang, Z., Cai, J., Dunford, M., \& Webster, D. (2014). Rethinking of the relationship between agriculture and the "urban" economy in Beijing: An input-output approach. Technological and Economic Development of Economy, 20, 624-647.

Yang, Z., Cai, J., Ottens, H. F. L., \& Sliuzas, R. (2013). Beijing. Cities, 31, 491-506.

Yang, Z., Cai, J., Qi, W., Liu, S., \& Deng, Y. (2015). The influence of income, lifestyle, and green spaces on interregional migration: Policy implications for China Population, Space and Place. http://dx.doi.org/10.1002/psp.1996.

Yang, Z., Cai, J., \& Sliuzas, R. (2010). Agro-tourism enterprises as a form of multifunctional urban agriculture for peri-urban development in China. Habitat In ternational, 34, 374-385.

Zasada, I. (2011). Multifunctional peri-urban agriculture-A review of societal demands and the provision of goods and services by farming. Land Use Policy, 28 , 639-648. 